\title{
Articles
}

\section{Loyalty, Subsidiarity, and Article 18 ECHR: How the ECtHR Deals with Mala Fide Limitations of Rights}

\author{
Corina Heri \\ Postdoctoral researcher, University of Amsterdam, Amsterdam, \\ the Netherlands \\ c.heri@uva.nl
}

\begin{abstract}
The ECHR system is premised on the presumption of state good faith. However, at least one article of the Convention does not adhere to this presumption. This is Article 18 ECHR, an idiosyncratic and underestimated provision that prohibits bad faith limitations of rights and is just starting to come into its own. Until recently, the Court's caselaw on this article made it almost impossible to invoke, given its narrow scope, accessory nature, and the sky-high burden of proof required to do so. Since the Grand Chamber revamped its approach to the provision in the 2017 Merabishvili judgment, the Court has started to find more regular violations of Article 18. But questions remain, such as how to distinguish Article 18 from the abuse of rights clause in Article 17, and how to deal with measures that have mixed legitimate and nefarious aims. This article unravels these and other questions and suggests ways to create a more coherent case-law that allows Article 18 to fulfil its intended role.
\end{abstract}

\section{Keywords}

abuse of power - bad faith compliance - Article 18 ECHR - Article 17 ECHR Merabishviliv. Georgia 


\section{Introduction}

In 1949, French statesman Pierre-Henri Teitgen addressed the Consultative Assembly of the Council of Europe, arguing that:

[d] emocracies do not become Nazi countries in one day. Evil progresses cunningly, with a minority operating, as it were, to remove the levers of control. One by one, freedoms are supressed, in one sphere after another. (...) It is necessary to intervene before it is too late. A conscience must exist somewhere which will sound the alarm to the minds of a nation menaced by this progressive corruption.'

This statement speaks volumes about the reasons for the founding of the Council of Europe, most importantly the 'never again' response to experiences leading up to and during the Second World War. This rationale is reflected in the Convention itself, perhaps nowhere as clearly as in Articles 17 and 18, which prohibit the abuse of rights and the abusive limitation of rights, respectively.

Article 18 of the European Convention on Human Rights ('ECHR') is succinct: it states merely that permitted restrictions to Convention rights 'shall not be applied for any purpose other than those for which they have been prescribed.' Despite its inconspicuous text, Article 18 pursues a very important aim: it is intended to safeguard against the decay of the rule of law and against undemocratic tendencies posing as legitimate rights restrictions which would, if uncontested, undermine and erode both human rights protections and the foundational principles of democracy. ${ }^{2}$ In other words, Article 18 ECHR exists to allow the European Court of Human Rights ('ECtHR') to find that member states have limited Convention rights in an abusive way, i.e. not for a permitted aim but for illegitimate reasons, such as for reasons of state ${ }^{3}$ or to suppress dissent, in a manner that is incompatible with and destructive of the principles of democracy and the rule of law. ${ }^{4}$ Its very existence thereby flies in the face of the - in any event rebuttable - presumption that the Council of Europe's member states will give effect to their Convention obligations in good faith. ${ }^{5}$

1 Council of Europe, Collected Edition of the 'Travaux Préparatoires' of the European Convention on Human Rights, Vol II (The Hague 1975) ('Collected Edition of the Travaux, Vol II') 6o-62.

2 H Keller and C Heri, 'Selective criminal proceedings and Article 18 ECHR: The European Court of Human Rights' untapped potential to protect democracy' (2016) 36(1) Human Rights Law Journal $1-10$.

3 Meaning here the abuse of power for political reasons (see the speech of Mr Teitgen in Council of Europe, Collected Edition of the 'Travaux Préparatoires' of the European Convention on Human Rights, Vol I (The Hague 1975) ('Collected Edition of the Travaux, Vol I') 130, 140.

4 Ibid.

5 Lutsenko v Ukraine App no 6492/11 (ECtHR, 3 July 2012), para 106. 
Article 18 ECHR is idiosyncratic: there is no provision like it in the other regional or international human rights treaties, ${ }^{6}$ although - as will be discussed below - it is not entirely unparalleled, and comparisons to the European Union system and to the Inter-American system can be made. Furthermore, Article 18 has frequently been overlooked: until 2004, the Court had never found a violation of this provision. ${ }^{7}$ At the time of writing, it had found violations in 15 cases, with seven such findings since early 2018. These cases, which inter alia concerned the rights of human rights defenders, ${ }^{8}$ government-critical mediacompany owners, ${ }^{9}$ and opposition politicians, ${ }^{10}$ are closely linked with issues concerning the rule of law and foundational democratic principles. In the words of Başak Çalı, this case-law has been largely about 'a particular problem in decaying democracies, that of controlling or punishing opposition political movements or civil dissent.." ${ }^{11}$ Certain of these cases also evoke the 'political trial' or 'trial of elimination' defined by Judith Shklar as one in which 'the prosecuting party, usually the regime in power aided by a cooperative judiciary, tries to eliminate its political enemies' while 'scorn[ing] the principle of legality'.12

To what extent can Article 18 counter these types of issues? The article commences by discussing the evolution of the Court's case-law, beginning with the earliest relevant cases and the transformation brought about by the Merabishviliv Georgia judgment (below) and then turning to the impact of that seminal judgment on the Court's case-law (Part II.). In short, this part of the article maps the state of the current jurisprudence, and weighs in on the main debates that surround it by outlining a number of deficits in the Court's approach before, in, and since Merabishvili. After a brief comparative look at the provision in its international context (Part III), which hints that the provision, while not entirely unique, should not be minimised, the article turns to two main questions that contribute to the provision's enduring minimisation and threaten to do away with its meaning altogether. The first concerns the confusion of

6 WA Schabas, The European Convention on Human Rights: A Commentary (Oxford 2015) 623; F Tan, 'The Dawn of Article 18 ECHR: A Safeguard Against European Rule of Law Backsliding?' (2018) 9(1) Goettingen Journal of International Law 109-141, 119.

$7 \quad$ Gusinskiyv Russia (2004) 41 EHRR 281.

8 Rasul Jafarov v Azerbaijan App no 69981/14 (ECtHR, 17 March 2016); Aliyev v Azerbaijan App nos 68762/14 and 71200/14 (ECtHR 20 September 2018).

$9 \quad$ Gusinskiy (n 7$)$.

$10 \quad$ Navalnyy v Russia (2018) 68 EHRR 25; Merabishviliv Georgia App no 72508/13 (ECtHR, 28 November 2017); Selahattin Demirtaşv Turkey (No 2) App no 14305/17 (ECtHR, 20 November 2018).

11 B Çal, 'Coping with crisis: Whither the Variable Geometry in the Jurisprudence of the European Court of Human Rights' (2018) 35(2) Wisconsin International Law Journal 237$276,266$.

12 JN Shklar, Legalism: Law, Morals, and Political Trials (Cambridge 1964) 149. 
the provision's scope, the intended understanding of which is traced back to the vision of the Convention's drafters (Part IV.). This section provides a defence of the scope of Article 18, focusing particularly on whether, and how, the provision can be distinguished from the abuse of rights provision contained in Article 17. In this regard, an argument is made for a clear distinction between the scopes of the two provisions, based on the premise that the two do not in fact overlap, and that Article 18 is a lex specialis to Article 17. It is argued here that while both provisions were intended to combat counter-democratic tendencies, they do so in entirely separate ways. The confusion of the two provisions is to some extent a symptom of the abolition by the Court in Merabishvili of the former bad faith standard without a satisfactory replacement. For this reason, the next section (Part v) turns to the issue of bad faith, and how the Court approaches it. It is argued here that the Court's approach to measures with mixed aims post-Merabishvili is exceedingly problematic, because it buries the issue of bad faith in discussions about predominance and reprehensibility, and because it tolerates, and thereby legitimises, non-predominant degrees of bad faith by states, or bad faith by certain loyal states. Altogether, what this tells us is that the Court still appears to be divided about the purpose of Article 18 and the best way to approach bad faith by states, and that this lack of a clear and united direction renders the approach to the provision disjointed and counter to its intended purpose.

According to its travaux préparatoires, Article 18 was intended to safeguard against what has been termed 'détournement de pouvoir' (expressed in English as 'misapplication of power', although the Court has also called this 'misuse of power'13) assailing 'the ideals and values of a democratic society governed by the rule of law'.14 This provision does not cover the failure of individuals to act in good faith in exercising their rights, ${ }^{15}$ the failure of applicants to exercise their right of petition in good faith, ${ }^{16}$ or the failure of states to cooperate with the Court. ${ }^{17}$ It does not even necessarily apply to situations in which states overtly flout the Convention's standards. ${ }^{18}$ Instead, it applies only to the

13 Merabishvili (n 10) para 283.

14 Council of Europe, Collected Edition of the 'Travaux Préparatoires' of the European Convention on Human Rights, Vol IV (The Hague 1977) ('Collected Edition of the Travaux, Vol IV') 258-269; Merabishvili (n 10) paras 154 and 303; Keller and Heri (n 2) 3; Tan (n 6) 114-115.

15 Pentikäinen $v$ Finland App no 11882/10 (ECtHR, 20 October 2015) para 90. On the abuse of rights provision in Article $17 \mathrm{ECHR}$, see below.

16 Gross $v$ Switzerland App no 67810/10 (ECtHR 30 September 2014) paras 28-37.

17 On the state's duties under Article 38 ECHR and Rule $44 \mathrm{~A}$, Rule $44 \mathrm{~B}$, and Rule $44 \mathrm{C}$ of the Rules of Court, see Al Nashiriv Poland (2014) 6o E HRR 393.

18 As allowed for example in Russia by law N 7-ФК3 (Federal Constitutional Law on the Introduction of Amendments to the Federal Constitutional Law 'On the Constitutional 
activities of states when limiting rights for non-permitted purposes while feigning a legitimate aim.

For decades after the entry into force of the ECHR, the Court largely ignored Article 18, and the provision therefore attracted little attention from scholars. While the provision was invoked early on - the Commission first considered a corresponding claim in the $196 \mathrm{os}^{19}$ - the Court did not find its first violation until Gusinskiy v Russia, in 2004. ${ }^{20}$ Today, Gusinskiy is one of only fifteen cases in which the Court has found a violation of Article 18. This jurisprudence has recently gained some momentum, with the seven most recent violations all being found since the beginning of $2018 .{ }^{21}$ But despite this, Article 18 continues to be overlooked and misunderstood - to repurpose Rory O'Connell's description, it is a real 'Cinderella' provision. ${ }^{22}$

The development of the provision's meaning in the Strasbourg caselaw has faltered largely because its application faced a number of hurdles. These hurdles are not intrinsic to the provision or attributable to poor arguments brought by applicants, but are instead of the Court's own - seemingly intentional - making.

First, there is the provision's accessory nature, which is to some extent responsible for its Cinderella-like position. Like Article $14 \mathrm{ECHR}$, Article 18 is non-autonomous, and must be invoked together with another right or freedom in the Convention. Until recently, the Court regularly found that it was not

Court of the Russian Federation', approved by the state Duma on 4 December 2015 and by the Federation Council on 9 December 2015; entered in force on 14 December 2015). Another example of flagrant flouting of the Convention is the UK response to the Hirst judgment (Hirst $v$ the United Kingdom (No 2) (2005) 42 EHRR 41) and other judgments concerning prisoner voting rights, as highlighted in Committee of Ministers, Interim Resolution CM/ResDH(2015)251, 9 December 2015.

19 De Beckerv Belgium, Commission (Plenary) Report (31) of 8 January 196o, Series B-2; Denmark, Norway, Sweden and the Netherlandsv Greece ('The Greek Case') ECHR 1969-XII 186.

$20 \quad$ Gusinskiy (n 7$)$.

21 Navalnyyv Russia (No 2) App no 43734/14 (ECtHR, 9 April 2019); Selahattin Demirtaş (No 2) (n 10); Navalnyy (n 10); Aliyev (n 8); Rashad Hasanov and Others $v$ Azerbaijan App nos 48653/13, 52464/13, 65597/13... (ECtHR, 7 June 2018); Mammadli $v$ Azerbaijan App no 47145/14 (ECtHR, 19 April 2018); Merabishvili (n 10);Merabishviliv Georgia App no 72508/13 (ECtHR, 14 June 2016); Rasul Jafarov (n 8); Ilgar Mammadov v Azerbaijan App no 15172/13 (ECtHR, 22 May 2014); Tymoshenko v Ukraine App no 49872/11 (ECtHR, 30 April 2013); Lutsenko (n 5); Cebotariv Moldova App no 35615/o6 (ECtHR, 13 November 2007); Gusinskiy (n 7); Natig Jafarov v Azerbaijan App no 64581/16 (ECtHR, 7 November 2019) (issued after the time of writing).

22 Referring to the well-known article on one of the Convention's other accessory provisions, Article 14 ECHR, by Rory O'Connell (R O'Connell, 'Cinderella Comes to the Ball: Art 14 and the Right to Non-discrimination in the ECHR' (2009) 29(2) Legal Studies 211-229). 
necessary to examine Article 18 because its findings under the co-invoked provision sufficiently addressed the complaint. ${ }^{23}$ In some instances, this decisionmaking was hard to follow because it was not clear why there was in fact no unaddressed issue under Article 18 , and the Court poorly reasoned this point. ${ }^{24}$ The Court was also reluctant to find a violation of Article 18 in conjunction with Convention provisions other than Article 5 .

Secondly, the Court required applicants to meet an extraordinarily high, though not always consistent, burden of proof, premised on the presumption that states fulfil their Convention obligations in good faith. ${ }^{25}$ In the most extreme cases, applicants had to provide 'incontrovertible and direct proof' of a violation of Article 18 and show that 'the whole legal machinery of the respondent state' had been 'ab initio misused, that from the beginning to the end the authorities were acting with bad faith and in blatant disregard of the Convention'. ${ }^{26}$ In other words, the Court tolerated measures having mixed purposes, i.e. that were motivated by co-existing permitted and illegitimate (nefarious, bad faith) reasons. So, for example, where applicants were detained both because of a 'reasonable suspicion' under Article 5(1)(c) ECHR and also because of unsound reasons, such as to remove them from the political scene or influence their business interests, this was determined to be permissible. It also required applicants to do the nearly impossible, namely to provide direct proof (i.e. not based on inferences or the circumstances) of bad faith by the state.

Together, the factors set out above left Article 18 with little scope of its own, and with little significance. ${ }^{27}$ Although there were admittedly a handful of cases in which the Court displayed some willingness to normalise the standards under Article 18, it continued to apply a 'very exacting standard of proof' and failed to make a clean break from the restrictive standards mentioned above. ${ }^{28}$ Then, in the 2017 Merabishvili v Georgia judgment, the Grand Chamber addressed these hurdles, and lowered them. ${ }^{29}$ That case concerned the pre-trial detention of a leading Georgian politician, who had allegedly been detained not just in order to remove him from the political scene, but also to pressure him to share politically sensitive information unrelated to the suspected offences. This case thus concerned the issue of how to approach co-existing legitimate and illegitimate aims, and how to prove the existence of an illegitimate one.

23 For early examples, see Engel $v$ the Netherlands (1976) 1 E HRR 647; Bozano $v$ France (1986) 9 EHRR 297, para 61.

24 Navalnyy and Yashin v Russia App no 76204/11 (ECtHR, 4 December 2014) para 116; Kasparov and Others $v$ Russia (No 2) App no 51988/07 (ECtHR, 13 December 2016) para 55.

25 On this see Keller and Heri (n 2).

26 Khodorkovskiy v Russia App no 5829/04 (ECtHR, 31 May 2011) paras 66 and 260.

27 As criticised in Keller and Heri (n 2).

28 See for example Ilgar Mammadov (n 21); Rasul Jafarov (n 8).

29 Merabishvili (n 10). 
In this case, the Court carved out an independent scope of application for Article 18 by finding, in analogy to the jurisprudence concerning Article 14, that examination of Article 18 complaints is warranted whenever they represent 'a fundamental aspect' of a case.$^{30}$ It also normalised the burden of proof and its distribution, aligning the requirements under Article 18 with those under other Convention provisions and applying the standard of proof 'beyond reasonable doubt. ${ }^{31}$ It then set up a criterion for deciding cases in which a given measure pursues both legitimate and illegitimate aims, i.e. the 'plurality of purpose' or 'predominant purpose' test, establishing that Article 18 is violated only where the latter, nefarious purpose predominates.

In other words, since Merabishvili, it is no longer up to applicants to prove bad faith on the part of the authorities, as previously required, and it is not necessary to demonstrate that a measure exclusively pursues a prohibited purpose. Instead, the Court requires only proof 'beyond reasonable doubt', and inferences about state behaviour are possible, as is recourse to contextual or circumstantial information. Measures that are found to pursue purely nefarious motivations, i.e. those that only aim at extraneous purposes, will violate Article 18, whereas those where the authorities happen to attain some prohibited purpose or advantage while mainly pursuing a legitimate one do not fall under 'the object and purpose of Article 18, which is to prohibit the misuse of power. ${ }^{32}$ Those cases that fall in between, namely measures with mixed purposes - i.e. both permitted and non-permitted aims - may violate Article 18 where the latter, nefarious purpose predominates. That predominance is measured by the reprehensibility of the purpose in question. The nature and degree of reprehensibility of the extraneous purpose, therefore, have become the new 'bad faith'.

This seems like an applicant-friendly development, and in many ways it is. However, Merabishvili has left room for questions, not least because the judgment was issued by a divided majority: only five out of the Grand Chamber formation's total of 17 judges actually agreed with the introduction of the predominant purpose test. That test also has a number of flaws.

For one, it continues to endorse politically-motivated prosecutions and tolerate bad faith, as long as it is not the predominant purpose of a measure (i.e. it tolerates measures with an 'unhealthy core') ${ }^{33}$ It also does not provide

\footnotetext{
$30 \quad$ Ibid para 291.

31 Ibid para 314.

32 Ibid para 303.

33 B Çal, 'Merabishvili v. Georgia: Has the mountain given birth to a mouse?' (Verfassungsblog, 3 December 2017) <https://verfassungsblog.de/merabishvili-v-georgia-has-the -mountain-given-birth-to-a-mouse/> accessed 9 December 2019.
} 
guidance on how to objectively assess multipurpose interferences, or how to remedy violations of Article $18 .{ }^{34}$ It emphasises the reprehensibility of the nefarious purpose, but does not clarify why this should inform the degree to which the nefarious purpose motivated a given act, or whether it was predominant. ${ }^{35}$ The judgment also excludes reliance on contextual evidence that is not related to the primary facts of the case. ${ }^{36}$ Furthermore, it does not resolve the question of whether Article 18 can be invoked together with Article 6 ECHR, the right to a fair trial, given that the latter provision does not textually provide for limitations. ${ }^{37}$ Lastly, Floris Tan has pointed out that finding that Article 18, like Article 14, must be examined when it represents a 'fundamental aspect' of a case, does not mean that the Court will always find it necessary to examine even meritorious Article 18 claims. ${ }^{38}$ In other words, and to continue the fairytale analogy, Article 18, our Cinderella, has now managed to enter the ballroom. But its story is far from over, and it still has a number of challenges to face.

Since Merabishvili, the Court has issued six judgments on Article 18. This part of the article looks at the judgment that confirmed its change of approach, the judgment of the Grand Chamber in Navalnyy, and what followed. It thereby elides three interim judgments - Aliyev, Rashad Hasanov, and Mammadli, all against Azerbaijan. ${ }^{39}$

\subsection{Confirmation of the Change of Approach (Navalnyyv Russia)}

2.1.1 The Judgment

The fragile majority's (or really, minority's) finding in Merabishvili was bolstered by the Navalnyy $v$ Russia Grand Chamber judgment, issued in 2018.40 Navalnyy concerned a well-known Russian opposition leader, blogger, and political activist who had, on seven separate occasions between 2012 and 2014, been arrested at peaceful public gatherings and convicted of administrative

34 Merabishvili (n 10) para 37 (joint concurring opinion of Judges Yudkivska, Tsotsoria and Vehabović).

37 Navalnyy v Russia App no 101/15 (ECtHR, 17 October 2017) para 88.

$38 \quad$ Tan (n 35) para 6.

39 All cited above.

$40 \quad$ Navalnyy $\left(\mathrm{n}_{10}\right)$. 
offences. Taking Merabishvili into consideration, the Grand Chamber considered Mr Navalnyy's Article 18 complaint to be 'a fundamental aspect' of the case, and decided to examine it. This is not the only aspect of Merabishvili reiterated here: the Court also confirmed the accessory but nonetheless autonomous nature of Article 18, the need to examine Article 18 claims that make up a 'fundamental aspect of the case', and the Merabishvili approach to the burden of proof. ${ }^{41}$ It also recalled the 'plurality of purpose' test and the finding in Merabishvili that the purpose of a given measure is not necessarily fixed, but can change over time. ${ }^{42}$

At the same time, the Court dramatically limited the scope of its examination under Article 18. It did this by, without much explanation, deciding to consider only two out of the seven events about which the applicant had complained. With regard to these two episodes, it had already found previously in its judgment that the authorities' actions lacked a legitimate aim. As a result, under Article 18, there was no need to balance permitted against illegitimate aims, or in other words to apply the predominant purpose test. The Grand Chamber therefore directly set about determining whether the measures in question had an identifiable ulterior motive. To do so, it suddenly, and without much explanation, looked at all seven episodes collectively and determined that on this basis 'a certain pattern may be discerned', whereby 'the pretexts for the arrests were becoming progressively more implausible. ${ }^{43}$ On this basis, the Court found that the applicant's claim that his freedom of assembly had become 'a particular object for targeted suppression' was coherent. ${ }^{44}$

In other words, the Court established that there was an ulterior purpose at play, and that this purpose was the sole motivation for the measures in question. The Court's reasoning here built on Merabishvili, which focused not on bad faith but on the purpose's 'nature and degree of reprehensibility' to determine whether an illegitimate purpose was an issue for Article 18, as opposed to simply a question of the 'normal' rights limitations regime and the legitimate aim criterion. ${ }^{45}$ As a result, the Court went on to examine the reprehensibility of the purpose at stake, and noted that the core of the applicant's Article 18 complaint was that he was prosecuted as an opposition politician and not as a private person, thereby negatively affecting 'the very essence of democracy as a means of organising society'46 Applying the normalised Merabishvili burden

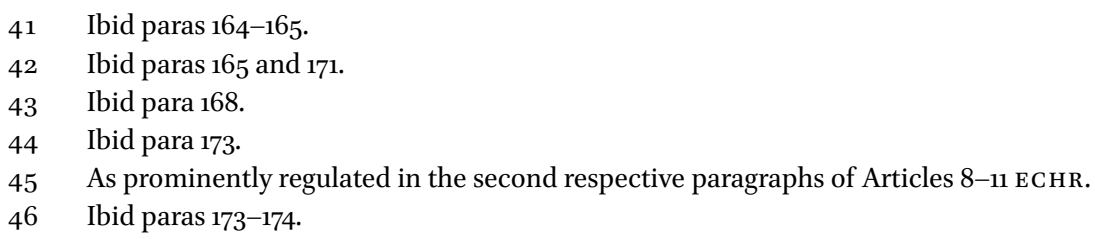


of proof, the Court considered the ulterior purpose of the two episodes in question to be established beyond a reasonable doubt, and found a violation of Article 18 in conjunction with both Articles 5 and $11 .{ }^{47}$

The Court had previously left open the question of how to address violations of Article $18 .{ }^{48}$ Now it provided some guidance by exercising its powers under Article 46 ECHR and making a consequential order ${ }^{49}$ about how its judgment was to be executed. ${ }^{50}$ Rendering Navalnyy a quasi-pilot judgment, the Court called for the state to take 'appropriate legislative and/or other general measures' to secure a mechanism requiring the domestic authorities to duly consider the importance of freedom of assembly and to display 'appropriate tolerance towards unauthorised but peaceful gatherings' that only create a minor disturbance, as well as to give due consideration to the legitimate aim requirement, and to fairly balance that aim and the rights of the individual. ${ }^{51}$

\subsection{2 \\ Enduring Problems with the Court's Approach, and Some New Ones}

Navalnyy was decided by a more solid majority than Merabishvili, with fourteen judges voting for the finding of a violation of Article 18, and only three against. By relying on Merabishvili and confirming many of its core elements, the Court in Navalnyy bolstered its authority and contributed to greater clarity and certainty about its change of approach to Article 18 in a variety of respects, especially with regard to the question of the provision's scope and the burden of proof. At the same time, the Grand Chamber failed to provide clarity about a number of other issues, especially when it comes to measures with mixed aims.

The first question is raised by the three minority judges in Navalnyy, who joined by two members of the majority - wrote a separate opinion in which they argued that Article 17 ECHR, not Article 18, should have been applied to the case. They argued that Article 17, because it does not require proof of ulterior purpose, would have allowed the Court to take into account all seven events about which the applicant complained, and not just two of them. In their view, while both Articles 17 and 18 concern abuses of power, only Article 18 requires proof of an ulterior purpose, wherefore this provision may be

$47 \quad$ Ibid paras $175^{-176 .}$

48 Çalı (n 33).

49 H Keller and C Marti, 'Reconceptualizing implementation: The judicialization of the execution of the European Court of Human Rights' Judgments' (2016) 26(4) European Journal of International Law 829.

50 Navalnyy (n 10), para 186.

$5^{1}$ Ibid. 
'redundant and unnecessary'. ${ }^{2}$ They further argued that 'Article 18 is a subset of Article 17. The concept of abuse of rights is broader than that of misuse of power'.53

In other words, the minority here argued that the scopes of Articles 17 and 18 overlap, and encouraged preference for the application of - in their view the broader provision, Article 17, given its comparative ease of application. However, as will be discussed in more detail below, this reasoning is difficult to follow, not least because Article 17 lacks the bad faith connotation of Article 18. That connotation may have been made implicit since Merabishvili, but the two provisions continue to cover different situations. In the relevant jurisprudence, Article 17 has been invoked mostly to prevent groups and individuals from abusively relying on rights, while abusive rights limitations by states have been addressed under Article 18.54 Furthermore, in a case such as this one, it seems counter-intuitive to disapply a more specific provision with a higher threshold and the potential to capture the nefariousness of the purpose at play in order to apply a more general norm that does not pack the same punch. In other words, assuming that the scopes of the two provisions even overlap - which, as argued below, is not the case - Article 18 should be considered the lex specialis as a matter of general principle, given its greater specificity. If the aim is to capture all seven episodes at stake, then what is needed is a clarification of Article 18, and not a muddling of its scope with that of Article 17 .

Secondly, Navalnyy did not engage with Merabishvili's lengthy comparative law section, in which it considered among others the travaux to the ECHR, EU law, the Inter-American system, and the many domestic jurisdictions where the administrative law notion of misuse of power is well-known. ${ }^{55}$ Based on that comparative section, the Court established the foundations of the predominant purpose test, justifying its approach by holding that 'the preparatory works to the Convention clearly show that Article 18 was meant to be its version

$5^{2} \quad$ Navalnyy (n 10) para 25 (the partly concurring, partly dissenting opinion of Judges Pejchal, Dedov, Ravarani, Eicke and Paczolay).

$53 \quad$ Ibid para 26.

54 See Stern Taulats and Roura Capellera $v$ Spain App nos 51168/15 and 51186/15 (ECtHR, 13 March 2018) para. 41. Outliers include the invocation against Greece in The Greek Case (n 19) and the approaches concerning Article 17 as a prohibition of excessive limitations taken in Bîrsan v Romania App no 79917/13 (ECtHR, 2 February 2016) para 71 and Mozerv the Republic of Moldova and Russia App no 11138/10 (ECtHR, 23 February 2016) para 222. For an overview of scholarly opinion, see P de Morree, Rights and Wrongs Under the ECHR: The Prohibition of Abuse of Rights in Article 17 of the European Convention on Human Rights (Cambridge 2016) 27-28.

Merabishvili (n 10) paras 154-168. 
of the administrative-law notion of misuse of power. ${ }^{56}$ However, as will be argued below, to say that the travaux to Article 18 'clearly show' such a thing is an overstatement. The Court in Navalnyy stayed decidedly away from similar considerations, and limits itself to a rather incomplete review of the travaux. ${ }^{57}$ By doing so, it fails to contest - or confirm - the findings made in Merabishvili linking Article 18 to the administrative law notion of misuse of power, or to the findings of other bodies. In this regard, more clarity is needed, including an explanation of why Article 18 - a provision within a living instrument full of autonomous concepts - should reflect the administrative law notion of misuse of power, or the jurisprudence on the misuse of power by the EU, which is not based on good or bad faith and therefore does not reflect the same concerns as those that led to the drafting of Article 18.

The third question relates to the predominant purpose test as established in Merabishvili. Before Merabishvili, the Court applied a 'healthy core' test to Article 18. This meant that measures that were largely based on illegitimate aims could nonetheless be redeemed by evidence of some partial legitimate aim. ${ }^{58}$ In Merabishvili, it found that a 'healthy core' cannot redeem a measure that serves a predominantly illegitimate purpose. However, neither approach captures measures that, though largely legitimate, are nevertheless based partly on a nefarious motivation, or in other words that have a non-predominant 'unhealthy core'. Understanding predominance as reprehensibility, as the Court did in Merabishvili, does not do away with this, especially given the fuzzy nature of the latter concept. ${ }^{59}$ In Navalnyy, the Court avoided addressing this - or applying the plurality of purpose test at all - by examining only those two episodes entirely lacking a legitimate aim. By failing to look at all seven episodes, and focusing just on the two least controversial ones, the Grand Chamber seems to have made a conscious decision to avoid clarifying the predominant purpose test. It therefore appears that it has simply cherry-picked the 'easiest' cases to deal with under Article 18 - which in turn indicates less agreement among the majority judges on the Article 18 issue than the seemingly solid ${ }^{14-3}$ vote would indicate. ${ }^{60}$ How the Grand Chamber did this is troubling, not just because it previously admitted that the other five episodes had an uncertain legitimate aim, but also because there should be a clear separation between the issue of the legitimate aim and of nefarious purpose, which has become

\footnotetext{
$5^{6} \quad$ Ibid paras 305-306.

$57 \quad$ Navalnyy (n 10) para 51.

$58 \quad$ Khodorkovskiy and Lebedev v Russia App nos 11082/06 and 13772/05 (ECtHR, 25 July 2013) paras 906-907.

$59 \quad$ Merabishvili (n 10) para 307.

6o As argued in Tan (n 35).
} 
even more uneasy with the turn away from explicitly focusing on the issue of state bad faith.

The fourth question concerns the application of Article 18 together with Article $6 \mathrm{ECHR}$. It has been argued in the past that these two provisions cannot be invoked together because Article 6 does not textually provide for limitations, and Article 18 can apply only to rights containing an explicit limitations clause. ${ }^{61}$ The fact that a violation of Article 18 together with Articles 5 and 11 ECHR was found in this case is noteworthy in and of itself, because this is the first time such a finding has been made. Before 2018, the Court had only found violations of Article 18 together with Article 5, but it has since expanded on this by finding violations of Article 18 together with Article $8^{62}$ and, now, Article 11. However, the Grand Chamber did not determine whether Article 18 ECHR can be invoked together with Article 6, but instead focused on Articles 5 and 11. This is an issue that needs addressing in the future case-law given that there is no clear basis for such an exclusion and that it eliminates possible rule of law issues from the scope of Article $18 .^{63}$

Furthermore, it is not entirely clear how the order made under Article 46 in Navalnyy will actually help to correct the tendencies that gave rise to the rights violations found in that judgment, specifically the Article 18 violation. The Court established that the applicant in Navalnyy, a prominent opposition leader, was personally targeted. ${ }^{64}$ In light of the nature of the violation at stake here, it is not clear how the measures proposed will help to prevent targeted suppression of key political figures such as the applicant, especially assuming that such targeting is condoned at the highest echelons of state power.

It should also be noted that Navalnyy did not entirely follow Merabishvili. Not only did it fail to apply or even engage much with the predominant purpose test or to confirm Merabishvili's comparative method, but its approach to contextual evidence may also have constituted a low-key departure from Merabishvili. In Navalmyy, the Grand Chamber not only drew on other, comparable proceedings brought by the applicant to the Court, ${ }^{65}$ but had regard to 'converging contextual evidence' that corroborated increasingly severe responses by the authorities not only to the applicant, but also to other activists and, generally speaking, to public assemblies. ${ }^{66}$ This may be somewhat broader than the finding, in Merabishvili, that the Court could draw on contextual evidence

\footnotetext{
$61 \quad$ See Navalnyy (n 37) para 88.

62 Aliyev (n 8).

63 Keller and Heri (n 2).

64 Navalnyy (n 10) para 173.

65 Ibid para 171.

66 Ibid para 172.
} 
only in so far as this represented 'information about the primary facts, or contextual facts or sequences of events which can form the basis for inferences about the primary facts', although it is difficult to tell from the judgments with much certainty. ${ }^{67}$ At the very least, in any event, Navalmyy provides some further examples - additional to those discussed in Merabishvili - of what contextual evidence can look like for the purposes of Article 18.

\subsection{Applying the Predominant Purpose Test (Selahattin Demirtaş (No 2) $v$ Turkey)}

Five days after Navalnyy, the Court issued its second-most recent judgment on Article 18: Selahattin Demirtaş v Turkey (No 2). ${ }^{68}$ That case was decided by a Chamber, which would have considered itself bound to follow the Grand Chamber's pronouncements in Merabishvili and Navalmyy. Nevertheless, it raises interesting points.

Selahattin Demirtaş (No 2) concerned the chairman of a pro-Kurdish leftwing political party and member of the Turkish parliament until 2018. In 2015, after the perpetration of deadly acts of violence attributed to the PKK (Workers' Party of Kurdistan), the Turkish authorities terminated the then-ongoing peace process concerning the Kurdish question. In 2016, after a constitutional amendment regarding the rules of parliamentary immunity, the applicant was arrested along with other members of his party on suspicion of leadership of an illegal organisation and of having encouraged terrorism. At the time of the Chamber's judgment, he was still in pre-trial detention. While in detention, he stood in the 2018 Turkish presidential election.

Here, the Chamber found, by six votes to one, a violation of Article 18 taken together with Article 5(3). Applying the Merabishvilistandard of proof-beyond a reasonable doubt - it found that the extensions of Mr Demirtaş's detention, especially during two crucial campaigns - the 2017 post-coup referendum and the presidential election, respectively - had pursued a predominant ulterior purpose, namely to stifle pluralism and limit freedom of political debate. Under Article 46 ECHR, the Chamber unanimously ordered the Government to take all necessary measures to end the applicant's pre-trial detention. ${ }^{69}$

Like the Grand Chamber in Navalnyy, the Chamber here extensively quoted Merabishvili concerning the scope of Article 18. Its reiteration of the predominant purpose test, by contrast, was succinct: it noted that a limitation of rights may have both an ulterior purpose and a legitimate one, that Article 18 is only

\footnotetext{
$67 \quad$ Ibid para 330.

68 Selahattin Demirtaş (No 2) (n 10).

69 Ibid para 283.
} 
violated if the former predominates, that the predominant purpose of a measure may change over time, and that the determination of the predominant purpose depends on the circumstances. ${ }^{70}$

Applying these standards, the Court reiterated that the detention or prosecution of politicians, even during politically important moments, does not automatically mean that the state intended to restrict political debate, and added that 'Article 18 of the Convention can only be breached after a significantly high threshold has been crossed. ${ }^{71}$

This is true - even after its move away from an explicit bad faith requirement, the Court does not apply Article 18 wherever there is no legitimate aim. At the same time, this statement is worrisome because it harks back to high pre-Merabishvili standards for Article 18. However, the Court did not seem inclined to backtrack. Examining whether the predominant purpose here was to remove the applicant from the political scene, the Court held that most of the accusations against him were directly related to his political activity, and so they could not be detached 'from the general political and social background. ${ }^{72}$ Conducting a contextual analysis, the Court found that given various international documents on the situation, the applicant's political position, tensions in the Turkish political climate, and statements by the applicant's political opponents, it was 'understandable that an objective observer might suspect' that the extension of his pre-trial detention was politically motivated. ${ }^{73}$ It was also, it held, 'hard to deny' that the applicant's detention impacted important domestic political events. ${ }^{74}$ Even though there was a 'reasonable suspicion' justifying his pre-trial detention, the Court therefore held, 'there was also a political purpose behind his continued detention. ${ }^{75}$

In other words, the Court admitted the presence of mixed aims. On whether the illegitimate, political purpose was the predominant one, the Court held that restrictions on an individual's rights aimed not at that person as an individual, but due to their political position as an opposition leader, threaten the whole democratic system. ${ }^{76}$ The extension of the applicant's pre-trial detention, the Court held, pursued 'the predominant ulterior purpose of stifling pluralism and limiting freedom of political debate, which is at the very core of the

\footnotetext{
$70 \quad$ Ibid para $25^{8}$.

71 Ibid para 260.

72 Ibid para 263.

73 Ibid para 264 .

74 Ibid para 265 .

75 Ibid para 267.

76 Ibid para 272 .
} 
concept of a democratic society', as a result of which there had been a violation of Article 18 in conjunction with Article 5(3). ${ }^{77}$

This case shows the flexibility created by the finding, in Merabishvili, that the purpose of a given restriction of rights may vary over time. It also shows how far the Court has come in terms of deploying a contextual analysis under Article 18. It now emerges as rather clear that restrictions on opposition leaders' rights aimed at them as political figures, and not as individuals, will likely violate Article 18. This judgment does not, however, answer the questions posed above regarding the Navalmyy judgment, especially concerning the condoning of measures with an 'unhealthy core' - in other words, how to deal with political purposes that are not predominant. It is also possible to wonder whether the provision can or should apply to persons who are not political leaders or widely-known political figures, given that the repression of dissent is not the only imaginable way in which a state can act in mala fides when it comes to its human rights obligations.

This case has since been referred to the Grand Chamber, and it therefore represents the next opportunity to clarify some of the unanswered questions that persist in this context - should the Grand Chamber choose to make use of it. ${ }^{78}$

\subsection{Avoiding the Predominant Purpose Test (Navalnyy v Russia (No. 2)}

On 9 April 2019, the Court issued its most recent judgment on Article 18. This case also concerned Aleksey Navalnyy, the applicant in the Grand Chamber Navalnyy case. Here, he complained that he had been placed under house arrest for political reasons. His house arrest, which was imposed in the context of investigations for fraud, included a prohibition on communicating with the outside world. Mr Navalnyy complained under Articles 5 and 10, together with Article 18 ECHR, but the Court found that it needed to look only at Article 5 together with Article 18, given that the communications ban was 'indissociable from the applicant's house arrest. ${ }^{79}$

In its judgment, the Court again reiterated the key findings from Merabishvili. ${ }^{80}$ The Court had already found that Mr Navalnyy's house arrest was ordered unlawfully, and that the ban on communication with the outside world lacked a legitimate aim. Therefore, it found that it could - as the Grand Chamber had done in Navalnyy - 'dispense with an assessment of the issue of plurality of

77 Ibid paras $273^{-274}$.

78 ECtHR, 'Press Release: Grand Chamber Panel's Decision of 19 March 2019', EchR 097 (2019).

$79 \quad$ Navalnyy (No 2) (n 21) para 86.

$80 \quad$ Ibid para 90. 
purposes (...) and focus on the question whether, in the absence of a legitimate purpose, there was an identifiable ulterior one'. 81

In its assessment, the Court noted that the measures against the applicant had, as established by the Grand Chamber, 'become progressively more implausible', and that he had been 'specifically and personally targeted as a known activist'. ${ }^{2}$ The applicant's house arrest had been inappropriately long, and the communication ban became 'increasingly incongruous' over time. ${ }^{83}$ Noting also the 'broader context of the Russian authorities' attempts to bring the opposition's political activity under control', as discussed by the Grand Chamber, the Court found that the restrictions on the applicant's Article 5 rights pursued the purpose of suppressing political pluralism, which constituted an ulterior purpose, and 'attained significant gravity'. ${ }^{4}$ There had accordingly been a violation of Article 5 together with Article 18 .

This case, again, takes some shortcuts. It is not clear why Article 10 was not considered along with Article 5 - the argument that the limitations on the applicant's communications, which were 'increasingly incongruous' and lacked a connection to the criminal investigation, were part and parcel of his deprivation of liberty is not convincing. In this regard, it would be useful for the Court to examine Article 18 together with Article 10, and distinguish a general 'chilling effect' from a violation of Article $18 .^{85}$ This would be important not only in the interest of clarity and predictability, but because it would allow for the Court to deploy the power of Article 18 against bad faith limitations of freedom of speech instead of conflating them 'simple' violations of Article 10 that involved a chilling effect. Focusing on the wider public role played by the applicant could be one way of doing this, albeit not a failsafe one. Furthermore, the Court again avoided applying the predominant purpose test by simply noting that the measures in question lacked a legitimate aim according to its assessment. It lastly emphasised the 'gravity of the ulterior purpose', which is strange, given that it gave little reason for why this purpose was so grave, why that gravity matters, or when an ulterior motive is not grave.

Like the Grand Chamber's Navalmyy judgment, Navalnyy (No 2) continues to avoid the unhealthy core problem, i.e. the fact that the Court lacks a convincing and transparent approach to dealing with cases with mixed legitimate (good faith) and illegitimate (bad faith) aims. As a result, the Merabishvili test continues intact.

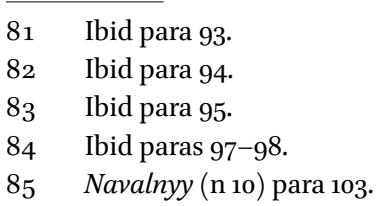


The above has noted a number of shortcomings in the Court's approach to Article 18. Before presenting an account of what form it should take, in terms of scope (as opposed to Article 17) and of substance (in the sense of maintaining the ability to address bad faith), the present section makes an excursus to debunk a possible hurdle in this regard, which is the perceived idiosyncrasy of Article 18 as discussed at the outset of this article. Admittedly, Article 18 ECHR is idiosyncratic in the sense that there is no provision quite like it in any of the other regional or international human rights treaties. ${ }^{86}$ While there may not be a provision exactly like it, however, the provision is not entirely unparalleled.

For one, comparisons to the safeguarding of the rule of law and foundational values of the European Union enshrined in Article 7 TEU have been made, ${ }^{87}$ and the ECtHR has also cited the CJEU's misuse-of-power jurisprudence in the context of its jurisprudence on Article 18.88 Arguably, however, both Article $7 \mathrm{TEU}$ and the CJEU's jurisprudence are quite different from Article 18 - especially the CJEU's misuse of power jurisprudence, which is largely about the introduction of EU measures for a purpose other than the one stated. For example, the argument that a Directive on tobacco products was intended not just to harmonise legal differences between states so as to facilitate the functioning of the EU internal market, which was its purported aim, but that it was also a covert public health measure. ${ }^{89}$ In other words, the jurisprudence concerns allegations by states that an EU organ has exceeded its powers, taking a measure 'solely, or at the very least chiefly, for ends other than those for which the power in question was conferred or with the aim of evading a procedure specifically prescribed by the Treaty for dealing with the circumstances of the case. ${ }^{90}$ While the reasoning here is clearly reminiscent of Article 18, the orientation of this jurisprudence, i.e. to constrain the powers granted to a supranational organisation by states, is quite different.

In other words, the comparisons made by the Court in the context of Article 18 are not particularly convincing as a matter of substance, or of methodology, given that it is not clear how the comparative material in question was selected or why the instruments in question are particularly relevant for the

\footnotetext{
$86 \quad$ Schabas (n 6); Tan (n 6).

87 Consolidated version of the Treaty on European Union [2008] OJ C115/13.

88 Merabishvili (n 10) paras 155-156.

89 Case C-491/01 The Queen $v$ the Secretary of State for Health, ex parte British American Tobacco (Investments) Ltd [2002] ECR I-11453.

90 Joined Cases C-274/11 and C-295/11 Kingdom of Spain $v$ Council of the European Union [2013] para 33 .
} 
interpretation of Article 18. It is not clear why no comparison has been made, for example, to the EU's Rule of Law Framework, which was launched in 2014. ${ }^{91}$ And when it comes to the EU Charter of Fundamental Rights, that instrument contains no parallel to Article 18, but Article 54 of the EU Charter does contain a provision almost identical to Article $17 \mathrm{ECHR}$, while Article 52(1) provides that limitations on rights must 'genuinely meet' a legitimate aim. ${ }^{92}$ These may be more appropriate comparisons to Article 18; indeed, it is rather unexpected that the Court has taken an administrative-law tack instead.

Furthermore, the Inter-American human rights system is relevant here. Not only does the interpretation of Article 30 of the Inter-American Convention of Human Rights display parallels to Article 18,93 but the Inter-American Court also has some relevant jurisprudence concerning the misuse of power, which the Court has mentioned, but from which it has not drawn any apparent conclusions to date. ${ }^{94}$ In this regard, it is interesting to note two recent cases against Venezuela, where the Court found that Hugo Chavez's government had taken measures that, while allegedly pursuing a legitimate aim, had in fact aimed to silence the opposition and critical voices in the country, and had therefore constituted a 'desviación de poder' or misuse of power. ${ }^{95}$ Along with arbitrary state action, the Inter-American Court held, the 'desviación de poder' exists when state action has 'a motivation or purpose diverging from that of the norm that confers a power to act on the state authority'. ${ }^{96}$ This seems like a rather straightforward parallel to the case-law of the ECtHR under Article 18. This impression is strengthened by the fact that, in these cases, the InterAmerican Court even referred to the early ECtHR jurisprudence on Article 18, specifically Gusinskiy, Lutsenko, and Cebotari, as examples of how to test state action for arbitrariness. ${ }^{97}$

These examples are mentioned here to show that it is not correct to view Article 18 as entirely unique or an outlier. More work is needed to determine

91 Communication from the Commission to the European Parliament and the Council, 'A New EU Framework to Strengthen the Rule of Law' Сом/2014/0158 final (11 March 2014).

92 EU Charter of Fundamental Rights [2012] OJ C326, 391-407.

93 The Word 'Laws' in Article 30 of the American Convention on Human Rights, Advisory Opinion OC-6/86, Inter-American Court of Human Rights Series A No 6 (9 May 1986) para $18(\mathrm{~b})$.

94 Granier et al (Radio Caracas Television) v Venezuela, Inter-American Court of Human Rights Series C No 293 (22 June 2015) paras 184-99 (as mentioned in Merabishvili (n 10) paras 157-160).

95 Granier et al (n 94) paras 184-99; San Miguel Sosa and Others $v$ Venezuela, Inter-American Court of Human Rights Series C No 348 (8 February 2018) para 150.

96 San Miguel Sosa (n 95) para 121 (translated from the original Spanish by the author).

97 Granier (n 94) fn 273; San Miguel Sosa (n 95) fn 189. 
whether and to what extent comparisons are possible here. In the meantime, what is indicated by the Court's current approach in this context, as per the Merabishvili judgment, is a failure to recognise the proper nature and role of Article 18 ECHR as discussed below. In other words, the Court's current approach minimises the role of Article 18, which - for the reasons set out in the following two sections - is problematic.

Together, Merabishvili and the first of the two Navalnyy cases discussed above lowered some of the hurdles facing applicants complaining of a violation of Article 18. Other hurdles were not far behind, however. So, for example, there is still the issue of the degree of 'ulterior purpose' that an act must pursue in order to contravene Article 18 - i.e. the question of whether Article 18 is violated where a given measure pursues a plurality of purposes, with the nefarious purpose not being the dominant one. ${ }^{98}$ As noted above, it has also been argued that Article 18 cannot be invoked together with Article $6 \mathrm{ECHR}$, the right to a fair trial, because that provision does not textually provide for limitations. ${ }^{99}$ Lastly, it has been argued that Article 17, the ECHR provision on the abuse of rights, and not Article 18, should be applicable in certain cases brought under the latter heading. ${ }^{100}$ The present section (v) and the one that follows (VI) will unpick some of these questions, in part by conducting a deep dive into the travaux préparatoires to the Convention. This section (v) will look at the distinction between Articles 17 and 18, while the one that follows (VI) will discuss why maintaining a potent Article 18 matters, and discuss the issue of mala fide under the provision.

\subsection{The Problem at Hand}

As mentioned above, in the Navalnyy Grand Chamber judgment, five judges argued in their separate opinion that Article 17 ECHR, the ECHR's abuse of rights provision, rather than Article 18, should be applicable in certain cases brought under the latter heading. ${ }^{101}$ In their lengthy opinion, the judges trawled the travaux préparatoires and the Court's case-law to find that 'from its very

\footnotetext{
$98 \quad$ Navalnyy (n 10) para 165, citing Merabishvili (n 10) para 307.

99 See Navalnyy (n 37) para 88.

100 Navalnyy (n 10) para 25 (the concurring, partly dissenting opinion of Judges Pejchal, Dedov, Ravarani, Eicke and Paczolay).

101 Ibid para 161 (the arguments of the state party and the partly concurring, partly dissenting opinion of judges Pejchal, Dedov, Ravarani, Eicke and Paczolay).
} 
beginning, Article 17 was aimed not only at enabling states to take measures against threats from groups or individuals to democratic society, but also (and perhaps even more so) at preventing states from a totalitarian drift. ${ }^{102}$ In other words, they considered that Articles 17 and 18 have the same aim, but that 'Article 18 is more difficult to apply' given that it not only requires abuse of power, but also proof of bad faith. ${ }^{103}$ They reduce this to two possibilities: in one, 'Article 18 only lays down in a more formal way the prohibition already provided for in Article 17', and in the other, the reverse is true, and 'it is perhaps Article 18 - and not Article 17 - which is redundant and unnecessary' given that Article 17 is 'more than capable' of allowing 'identification of the genuine unacknowledged motives of the author of the particular challenged act.'104 In short, they argue, Article 17 is about abuse of rights or of power, and Article 18 is about misuse of power, as a result of which 'Article 18 is a subset of Article 17.105 The following will argue that while the two provisions have a similar aim - to prevent the creeping return of totalitarianism - the judges drew an untenable conclusion from this shared origin. To unpack and refute their argument, the following section will dive deeply into the travaux on both provisions.

\subsection{What the Travaux Tell Us}

The minority judges in Navalnyy referred extensively to the travaux to build their argument that Article 17 aims, perhaps predominantly, 'at preventing states from a totalitarian drift.'106 There are some problems with this, however, and a different interpretation is possible.

To support their argument, the judges rely on the Registry's travaux information documents. ${ }^{107}$ These documents, which are not exhaustive, overlap to some extent for Articles 17 and 18, and both refer to passionate calls for safeguards against the creeping return of totalitarianism. These documents are according to the Court's own disclaimer - internal, incomplete, and not suitable for citation. ${ }^{108}$ The document on Article 18 even admits, in a footnote,

\footnotetext{
102 Ibid para 14 (the partly concurring, partly dissenting opinion of Judges Pejchal, Dedov, Ravarani, Eicke and Paczolay).

103 Ibid para 24.

104 Ibid para 25.

105 Ibid para 26.

106 Ibid para 14 (the partly concurring, partly dissenting opinion of Judges Pejchal, Dedov, Ravarani, Eicke and Paczolay).

107 ECHR, 'Travaux Préparatoires to the Convention' <https://www.echr.coe.int/Documents/ Library_TravPrep_Table_ENG.pdf $>$ accessed 9 December 2019.

108 Ibid 3.
} 
that the remarks cited have 'equal, if not greater, relevance as concerns the history of the present Article $17^{\prime} .{ }^{109}$ Part of the reason for this overlap is that, in 1949, when many of the relevant comments were being made, there was not yet an Article 17 or an Article 18 - both of these provisions were inserted into the draft Convention in 1950. The other part of the reason for this confusion is that both provisions do indeed have the same aim, namely to prevent the sneaking return of totalitarianism. However, they do so rather differently.

It is noteworthy that both the information document for Article 17 and for Article 18 refer to a summer 1949 draft of the ECHR that contained a general limitations clause for Convention rights. ${ }^{110}$ At the time, arguments made by Greek and Turkish representatives for an abuse of rights provision akin to Article $17^{111}$ were rebutted on the basis that this had already been addressed, in that limitations clause. ${ }^{112}$ The general limitations clause was also understood as preventing rights limitations 'for reasons of State.'113 In other words, at the time, that general clause seems to have been understood as allowing both for the protection of rights against bad faith limitations, and for protecting the state from abusive reliance on rights. ${ }^{114}$

Things became more complicated rather soon after this. Because of differences of opinion amongst delegates about the level of precision necessary, ${ }^{115}$ two alternative drafts of the ECHR were prepared. Alternatives A and A/2 used the method of general enumeration of rights without specific exceptions, and instead included generally-applicable principles of limitation similar to those

109 Council of Europe, CDH (75) 11, 10 March 1975, 2, fn 3.

110 Which read: 'no limitations shall be imposed [on Convention rights] except those established by law, with the sole object of ensuring the recognition and respect for the rights and freedoms of others, or with the purpose of satisfying the just requirements of public morality, order and security in a democratic society'. Collected Edition of the Travaux, Vol I (n 3) 103 and 105. Reproduced in European Commission of Human Rights, 'Preparatory Work on Article 17 of the ECHR', Information Document DH (57) 4, 23 April 1957, 5, fn 1, and in European Court of Human Rights, 'Preparatory Work on Article 18 of the ECHR', Information Document DH (75) 11, 10 March 1975, 1.

111 Mr Düsünsel in the Debate in the Assembly of 8 September 1949, Council of Europe Doc DH (57) 4, 23 April 1957; Mr Callias in the explanatory memorandum to the Report to the Consultative Assembly of the Committee on Legal and Administrative Questions of 7 September 1949 (Collected Edition of the Travaux, Vol I (n 3) 258-295, para 16).

112 Debate in the Assembly of 8 September 1949, Council of Europe Doc DH (57) 4, 23 April 1957 in Collected Edition of the Travaux, Vol I (n 3) 14-283.

113 Report of the Legal Committee to the Consultative Assembly, 5 September 1949 in Collected Edition of the Travaux, Vol I (n 3) 192-213, para 14(b).

114 Council of Europe Consultative Assembly, Recommendation No 38 (Doc 108), 8 September 1949 .

115 See Collected Edition of the Travaux, Vol IV (n 14) 12. 
in Article 29 of the Universal Declaration of Human Rights. Alternative B and $B / 2$, based on a list of precisely defined rights submitted by the United Kingdom government, used the method of precise definition of rights and freedoms along with their limitations clauses and rules on derogation. ${ }^{116}$ While Alternatives A and B were premised on the idea that the proposal to create an ECtHR would be accepted, Alternatives $\mathrm{A} / 2$ and $\mathrm{B} / 2$ were planned around the eventuality that it would not be, and retained only the Commission as a body possessing jurisdictional powers. ${ }^{117}$

Alternatives $\mathrm{A}$ and $\mathrm{A} / 2$ contained a provision ${ }^{118}$ which is almost identical to today's Article 17 ECHR. ${ }^{119}$ The corresponding commentary stated that its aim was to 'protect the signatory states against activities which threaten the preservation of the democratic rights and freedoms themselves.' ${ }^{120}$ The commentary also explained that the provision had been inserted at the behest of the Turkish representative, who was concerned about accommodation of the Turkish legislation banning the dissemination of extremist ideas ${ }^{121}$ and the state's need to protect itself from activities that would lead to its territorial or moral disintegration, ${ }^{122}$ 'and was taken from the Draft Covenant of the United Nations. ${ }^{123}$ Indeed, the provision is taken almost word for word from what would later become common Article 5 of the International Covenant on Civil and Political Rights ('ICCPR') and the International Covenant on Economic, Social and Cultural Rights ('ICESCR'), which were being negotiated at Lake Success around the same time. ${ }^{124}$

\footnotetext{
116 Ibid 14-16.

117 Ibid 16.

118 Originally numbered as Article 8(a), later as 7(a) (see Council of Europe, Collected Edition of the 'Travaux Préparatoires' of the European Convention on Human Rights, Vol III (The Hague 1976) ('Collected Edition of the Travaux, Vol III') 224.

119 Doc A.8og, 7, translation from the French original in Council of Europe Doc DH (57) 4, 23 April 1957, 9.

120 Doc CM/WP I (50) 1, 13, in Council of Europe Doc DH (57) 4, 23 April 1957, 10; Collected Edition of the Travaux, Vol IV (n 14) 26.

121 Ibid 26.

122 Collected Edition of the Travaux, Vol III (n 118) 264.

123 Doc CM/WP I (50) 1, 13, in Council of Europe Doc DH (57) 4, 23 April 1957, 10; Collected Edition of the Travaux, Vol III (n 118) 266; Collected Edition of the Travaux, Vol IV (n 14) 26.

124 Art 5(1) ICCPR and Art 5(1) ICESCR. As per the report submitted to the United Nations Economic and Social Council by the Commission on Human Rights after its $5^{\text {th Session, }}$ 9-20 June 1949, Doc E71371, 25, to which the Committee of Ministers invited the Committee of Experts on Human Rights to pay due attention (Doc 116 (1949), para 6, 288-289). In all, see Council of Europe Doc DH (57) 4, 23 April 1957, 8.
} 
In parallel, and only a few months before the ECHR was adopted in November 1950, Article 18 came about via a late draft of alternative B and B/2. ${ }^{125}$ This happened around the time the decision was made to pursue Alternative $\mathrm{B}$, and amalgamate Alternative A into Alternative B. ${ }^{126}$ The amalgamated compromise draft retained both what eventually became Article 17 ECHR, and what became Article 18. ${ }^{127}$ The future Article 18 was contained in Article 13(2) of the amalgamated draft, right after an Article13(1) containing the non-discrimination norm that later became Article 14 ECHR. ${ }^{128}$ Together, these two provisions were to represent 'general principles' applicable to all Convention rights. ${ }^{129}$ From a systematic perspective it makes considerable sense that these two norms, namely what became the accessory Articles 14 and 18 ECHR, were originally part of the same article.

In other words, when combining the two alternative drafts, it was considered necessary to retain both Article 17 and Article 18. This supports the conclusion that the two provisions were intended have separate scopes of application. Considering that Article 18 was introduced as a general principle applying to the restrictions of Convention rights by the state, this would vindicate the argument that Article 18 has been correctly interpreted by the Court to date, and that Article 17 is meant to serve a different purpose, namely to prevent the abuse of rights by their bearers.

However, not much further guidance was provided about the reasons for adding Article 18 to the text. The Conference of Senior Officials did note that this provision concerned 'the application of the theory of the misapplication of power' (in French, 'la théorie du détournement de pouvoir'). ${ }^{130}$ It also noted that, in order to prevent states from abusing the right to arrest individuals in order to prevent them from committing a crime, that provision 'will have to be applied strictly'. ${ }^{131}$ The phrase 'misapplication of power' is used once more in the travaux, in an earlier discussion of Alternative A, where it was noted that 'by virtue of the general principles [of international law], cases of abuse of power constitute a violation of law'; in the French version, 'abuse of power' is

\footnotetext{
125 At the time referred to as Article 15(2). See New Draft Alternatives B and B/2, Doc CM/WP 4 (50) 9; A 1372 in Collected Edition of the Travaux, Vol IV (n 14) 190 and 258; also in Doc CM/ WP 4 (50) 9, 6, in Council of Europe Doc DH (75) 11, 6.

126 Collected Edition of the Travaux, Vol IV (n 14) 248 and 258.

127 Ibid 190, 226 and 274, then numbered as Articles 17 and 13(2); Council of Europe, Collected Edition of the 'Travaux Préparatoires' of the European Convention on Human Rights, Vol $\mathrm{V}$ (The Hague 1979) ('Collected Edition of the Travaux, Volv') 154.

128 Ibid 226,258 and 280 .

129 Ibid 258.

130 Collected Edition of the Travaux, Vol IV (n 14) 258.

131 Ibid 260.
} 
translated as 'détournement de pouvoir'.132 This supports the argument that the drafters intended to codify existing general principles of international law by introducing this provision.

This does not leave it entirely clear, however, what Articles 17 and 18 were meant to achieve, or where they came from. Carefully sifting through the travaux even further provides a little more context. In particular, many of the discussions by the drafters in the summer and early autumn of $195^{\circ}$ concerned the failure of the amalgamated draft Convention to safeguard democratic institutions. ${ }^{133}$ Most poignantly, Mr Teitgen suggested adding an Article 18(b) ECHR requiring the interpretation of rights in light of the general principles of international law. ${ }^{134}$ He argued that, absent a guarantee that Convention rights must be seen from the point of view of democracy, they risk being undermined. ${ }^{135}$ This is because, 'in a totalitarian regime, reasons of State are supposed to justify any State intervention.' ${ }^{136}$ Convention rights, he argued, are inseparable from democratic institutions, ${ }^{137}$ and the drafters needed to set up 'an international procedure capable of intervention right from the start', 'from the very first day, from the day of the assassination of a Matteotti, from the day of a Reichstag fire', to prevent the suppression of free institutions, free opinion, universal suffrage, and political opposition. ${ }^{138} \mathrm{Mr}$ Teitgen made a motion to append this Article 18(b), ${ }^{139}$ but it was not considered necessary to do so, as the majority of the drafters considered that such principles were in any event to be applied. ${ }^{140}$

\subsection{Why Distinguish Articles 17 and 18 ?}

With the above as a starting point, it can be argued that there is a clear and non-negligible difference between Articles 17 and 18 ECHR. Article 18 aims to protect individual rights bearers from abusive limitations of rights, i.e. from restrictions of rights based on a state's desire to protect itself and 'the political

\footnotetext{
132 Meeting of the Committee of Experts, Commentary on the Draft Convention, in Collected Edition of the Travaux, $\operatorname{Vol}$ IV (n 14) 30-31.

133 Collected Edition of the Travaux, Volv (n 127) 194 and 286-288.

134 Ibid 286.

135 Ibid 290.

136 Ibid 292.

137 Ibid 294.

138 Ibid 294 .

139 Council of Europe, Collected Edition of the 'Travaux Préparatoires' of the European Convention on Human Rights, VolvI (The Hague 1985) ('Collected Edition of the Travaux, Vol VI') 8 and 12.

140 Collected Edition of the Travaux, Volv (n 127) 50, 56, 62.
} 
tendency which it represents', thereby acting repressively 'against an opposition which it considers dangerous'. ${ }^{141}$ By contrast, Article 17 was meant to prevent abusive reliance on rights by rights bearers (i.e. using rights, for example freedom of expression, in a way that aims at the violation of others' human rights, for example to advocate for violence or hate or establish a dictatorship). This argument is admittedly not entirely uncontroversial, given the reference to states in Article $17 .{ }^{142}$ It is possible to provide a bit more context for this by means of three further comments.

First, even if Article 17 is only about relying on rights abusively, that need not render the reference to states in its text meaningless. A state (in addition to the 'groups' or 'persons' mentioned in the provision) could potentially do this, for example in the context of an inter-state application. This approach was taken - to some extent - in the 1969 inter-state 'Greek case', where it was submitted that the Greek government's derogation regime had violated Articles 17 and 18 , taken together with Article 15 ECHR. It is relevant for present purposes to note the arguments of the applicant governments, which submitted that Greece had aimed to destroy Convention rights and could therefore not rely on the right to derogate from the Convention under Article $15 \mathrm{ECHR}$, given that 'Article 15 and 17 were designed to protect democratic regimes against totalitarian conspiracies.' 143

Secondly, it is not clear why the Navalnyy minority thought that, because common Article 5 of the ICESCR and the ICCPR was the basis for Article 17 ECHR, Article 17 covers the same issues as Article 18 ECHR. ${ }^{144}$ The circumstances discussed by the minority - i.e. the fact that Article 5 ICCPR precludes extraterritorial rights violations ${ }^{145}$ and actions that violate the purpose and spirit of the Covenant - are unrelated to the scope of Article 18. Even if the UN Human Rights Committee's ('HRC's') approach did interpret Article 5 ICCPR as comparable to Article $18 \mathrm{ECHR}$, this should still not be used to draw conclusions about the ECHR. The reason for this is two-fold: first, we are talking about two autonomous instruments, and secondly, the ICCPR does not contain anything

\footnotetext{
141 Teitgen, speaking at the first session of the consultative assembly, in Collected Edition of the Travaux, Vol I (n 3$) 278$.

142 Navalnyy (n 10) (the partly concurring, partly dissenting opinion of Judges Pejchal, Dedov, Ravarani, Eicke and Paczolay).

143 The Greek Case (n 19) para 149, as pointed out in de Morree ( $\mathrm{n}_{54}$ ) 27-28.

144 Navalnyy (n 10) para 16 (the partly concurring, partly dissenting opinion of Judges Pejchal, Dedov, Ravarani, Eicke and Paczolay).

145 Ibid para 16 (which refers to Delia Saldias de Lopezv Uruguay, Communication No 52/1979, $\mathrm{CCPR} / \mathrm{C} / \mathrm{OP} / 1$ at 88 (1984) para. 12.3 and Lilian Celiberti de Casariego v Uruguay, Communication No 56/1979, CCPR/C/OP/1 at 92 (1984) para 10.3).
} 
like Article $18 \mathrm{ECHR}$, which may lead it to pursue different interpretations than under the ECHR, which contains both Articles 17 and 18. The HRC's practice is therefore not a convincing basis for the argument that the reference to 'states' in Article 17 ECHR has little role to play in the ECHR. ${ }^{146}$

Thirdly, we should recall that Article 18 covers limitations of rights applied with nefarious purposes. At the same time, limitable Convention rights themselves will be violated in the event that a limitation of rights simply lacks a legitimate aim. As a result, and in between these two constellations covering two different problems with the legitimate aim of a measure, namely either its abuse or its absence, it is not clear what the scope of application for Article 17 would be. If Article 17 does not relate to bad faith by the state, in other words, then it appears unnecessarily confusing to deploy it in this specific context, as compared to simply finding that a measure lacks a convincing legitimate aim and therefore represents a violation of the underlying right.

These three arguments counter the claim made by the Navalnyy minority, but they are perhaps not entirely convincing on their own. To strengthen them, the following section will turn to the case-law on Article 17.

\subsection{The Case-law on Article 17}

In the Court's early case-law, it was unclear at what point Article 17 ends and Article 18 begins, and it was not unheard of for applicants to invoke both provisions against states. ${ }^{147}$ The early case-law under Article 17 does indicate that this provision is aimed at preventing reliance on rights. For example, in its 1957 admissibility decision in the German Communist Case, the Commission used Article 17 to find that the rights invoked by the German Communist Party to contest its dissolution and prohibition did not apply given the need "to prevent totalitarian currents from (...) invoking the rights of freedom in order to suppress human rights". ${ }^{148}$ As the German Communist Party advocated a 'dictatorship of the proletariat', Article 17 precluded it from relying on any Convention rights. ${ }^{149}$

Today, the Court continues to take a similar approach to Article 17 , which is used vis-à-vis groups and individuals to 'negate the exercise of the Convention right that the applicant seeks to vindicate' when it comes to revisionist speech, the promotion of totalitarian ideologies, and hate speech, including incitement

\footnotetext{
146 de Morree (n 54) 69.

147 Sporrong and Lonnroth $v$ Sweden (1980) 5 E HRR 85.

148 German Communist Party $v$ Federal Republic of Germany App no 250/57 (ECtHR, 20 July 1957) para 4.

149 Ibid para 5 .
} 
to violence. ${ }^{150}$ Article 17 bars the reliance on Article $10 \mathrm{ECHR}$ to protect hate speech, a term that covers all forms of expression propagating, citing, promoting or justifying racial hatred, xenophobia, anti-Semitism, or other forms of hatred based on intolerance, but which may not be defined too broadly so as to safeguard the pluralism, tolerance, and openness that are necessary for a democratic society. ${ }^{151}$ This is the main theme of the case-law regarding Article 17.

Some commentators have argued that Article 17 contains two norms, one concerning the abusive reliance on individual rights by individuals and groups, and the other concerning the excessive limitation of rights by states. ${ }^{152}$ There is not much basis for this argument, and an alternative reading is possible, one that prohibits any actor - be they a state, group, or individual person - from relying on human rights so as to ultimately destroy or violate others' rights. ${ }^{153}$ This is a more coherent reading of the provision, and makes it unnecessary to force a distinction between 'destruction' of rights and their excessive limitation. This interpretation not only leaves Articles 17 and 18 with their own individual scopes of application intact - and therefore makes it unnecessary to declare any part of the Convention 'superfluous', which is a problematic assertion - but also corresponds to how these rights have been labelled in the Convention text, with Article 17 concerning the abuse of rights and Article 18 concerning limitations on the use of restrictions on rights. ${ }^{154}$

The separate opinion in Navalnyy seems to represent the first time any members of the Court have, in their official capacity, provided clarity about this issue at any length. ${ }^{155}$ To these judges, Article 17 does not contain two separate norms. Instead, it concerns 'not only - excessive - individual restrictions of the exercise of fundamental rights, but also a general system of limitations

150 Perinçek $v$ Switzerland (ECtHR, 2015 (extracts)) para 114. See also Fáber v Hungary App no 40721/o8 (ECtHR, 24July 2012) para 58; Garaudy v France ECHR 2003-IX (extracts); Witzsch $v$ Germany App no 7485/o3 (ECtHR, 13 December 2005), and Stern Taulats (n 54). In all, see de Morree (n 54).

$15^{1}$ Stern Taulat (n 54) para 41 (along with further references).

152 S van Drooghenbroeck, 'Larticle 17 de la Convention Européenne des Droits de l'Homme est-il indispensable?' (2001) 12(46) Revue trimestrielle des droits de l'homme 543-550; A Buyse, 'Prohibition of the abuse of rights' in P van Dijk and others (eds), Theory and Practice of the European Convention on Human Rights (5th edn, Antwerp 2018) 1086; P de Morree, 'Noot bij Navalnyy v. Rusland' (2019) 34(2) European Human Rights Cases para 7.

153 In this I agree with the minority judges in Navalmyy (Navalnyy (n 10) para 7 (the partly concurring, partly dissenting opinion of Judges Pejchal, Dedov, Ravarani, Eicke and Paczolay)).

$154 \mathrm{cf}$, however, Bîrsan ( $\left.\mathrm{n}_{54}\right)$ paras 71 and 73 . See also, for a less illuminating example, Mozer (n 54$)$.

155 Although others have touched upon it, for example Judge Serghides in Kasparov (n 24) para 26 . 
or actions going beyond what is necessary in a democratic regime. ${ }^{\prime 156}$ In their eyes, Article 17 thereby serves to capture overt abuses of power, excessive limitations of rights lacking ulterior purposes, or 'systems of violations', which they describe as 'a succession of incidents which, taken one by one, appear to be isolated and straightforward violations of a Convention right, but which, taken together, show a greater problem of systemic violations ultimately aimed at the destruction of the rights and freedoms provided by the Convention.' ${ }^{157}$

This is an intriguing proposal. To Paulien de Morree, this would allow the Court to tackle the erosion of democratic values and the rule of law, which only becomes visible when all measures and interventions by the state are examined in context. ${ }^{158}$ However, in the existing case-law, there is little to indicate that this is the (partial) purpose of Article 17, and the parts of the travaux to which the dissenting judges in Navalmyy referred in support of their argument are rather tenuously linked to this interpretation of Article 17. Neither is it clear where the lines between regular violations determined contextually, the pilot judgment procedure, and this type of application of Article 17 would lie. ${ }^{159}$ There are also other serious question marks around Article 17: aside from divergent views about its meaning and aim, it is unclear whether it contains both positive and negative state obligations, with which provisions it can be applied, or whether individuals can invoke it in the sense of an individual right to state protection from abuse of rights by others. ${ }^{160}$ To date, the Court has never found a violation of the provision, but only used it to disapply rights, often when Article 17 is invoked by the state. In other words, what we have here is yet another Cinderella provision.

To sum up, it can be noted - as Antoine Buyse has argued - that, because it appears to reiterate Article 18, Article 17 'seems rather superfluous as a protection against state abuse.'161 Some caveats apply - Buyse's statement does not account for the possibility that states could rely on the rights of one group to excessively limit those of another, or the (admittedly rare) constellation

156 Navalnyy (n 10) para 17 (the partly concurring, partly dissenting opinion of Judges Pejchal, Dedov, Ravarani, Eicke and Paczolay).

157 Ibid.

158 de Morree (n 152) para 11.

159 See L-A Sicilianos, 'The Involvement of the ECtHR in the Implementation of its Judgments: Recent Developments Under Article 46 ECHR' (2014) 32(3) Netherlands Quarterly of Human Rights $235^{-262 .}$

16o de Morree (n 54) 71-72.

161 A Buyse, 'Contested Contours: The Limits of Freedom of Expression from an Abuse of Rights Perspective - Articles 10 and 17 ECHR' in E Brems and J Gerards (eds), Shaping Rights in the ECHR (Cambridge 2013) 183-210, 188. 
discussed above, wherein states can abusively rely on rights, for example in inter-state cases.

Ultimately, it appears that one of the main sources of confusion here is the perspective from which Articles 17 and 18 are phrased. If we take Buyse's statement that Article 17 occupies 'a place halfway between "ordinary violations" and states of emergency", ${ }^{162}$ this becomes a bit clearer. From this perspective, the state can preclude reliance on rights (Article 17) or derogate from them (Article 15) in order to address threats to democratic society and other Convention values (alongside limiting rights the 'old fashioned' way). Article 18, on the other hand, protects rights bearers from threats to democratic society and fundamental Convention values posed by the state itself. While both provisions safeguard the same values, they do so in different ways and vis-à-vis different types of abuse.

By taking this approach, the scopes of both provisions retain their integrity. This is important: an interpretation that allows Article 17 to appropriate some or all of the scope of Article 18 is not only incoherent with the travaux and the Court's interpretation to date, but it also tosses aside the powerful punch packed by the finding that a state has limited rights when acting in bad faith for a nefarious purpose. In addition to this argument, based on the coherence of the Court's interpretation, it could be contemplated whether - as touched upon below - the era of backlash against the Court makes it particularly important to retain that punch, or perhaps even to reinforce it. ${ }^{163}$

In other words, the idea that Article 17 covers the same situations as Article 18 is difficult to maintain. To continue the analogy used above, Article 17 as thus understood would become a jealous stepsister squeezing her wronglysized foot into Cinderella's glass slipper: an ill-fitting impostor.

In addition to the issue of defending the scope of Article 18 against incursions by Article 17, another problem merits discussion here: the issue of state bad faith and how to deal with it. Most of the ECHR is premised on the presumption that states will fulfil their obligations in good faith. Article 18 is rather alone in going against this presumption, and instead focusing on state bad faith. The following will explore what this means, and its potential in times of growing backlash both against the Convention and against the values it

162 Ibid 191; de Morree ( $\left.\mathrm{n}_{54}\right)$ 81-82.

163 I am grateful to the anonymous peer reviewer who raised this point. 
enshrines. This is relevant here because the failure to understand the importance of the bad faith aspect of Article 18 is arguably at the core not only of confusion between the scopes of Articles 17 and 18, but more generally responsible for the Court's cautious and not always predictable case-law on the matter.

\section{1}

\section{'Unhealthy Cores' and the Enduring Problem of Mixed Aims}

The Court's predominant purpose test excludes from the scope of Article 18 limitations of rights with a predominantly legitimate purpose but a subsidiary nefarious purpose. In other words, to put it bluntly, it seems that where the nefarious purpose makes up $50 \%$ or less of the state's motivation for a given limitation of rights, this does not fall under Article 18.

Through this approach, the Court is condoning, even legitimising restrictions of rights that constitute some but not a predominant misuse of power. As demonstrated by the Navalnyy case, where the Court only considered the two episodes regarding which it had previously found no legitimate aim under Article 18, the Court is thereby cherry-picking 'easy' cases for the purposes of this provision. That is not to say that there are not good reasons for restraint in this context, which, after all, concerns a serious allegation about the state's use of power and treads deep into the arena of domestic politics. However, in $\mathrm{Na}$ valnyy, the Court did not produce a single reason, convincing or otherwise, for its decision to exclude five of the seven episodes concerned, except for the fact that they had a legitimate aim under Article 11 - a reason that, given that Article 18 can be violated nonetheless, is irrelevant.

There is no mathematical formula available for calculating the preponderance of a given aim when a measure with mixed aims is at stake. As established in Merabishvili, the Court instead currently assesses all the circumstances of a case, as well as 'the nature and degree of reprehensibility of the alleged ulterior purpose' (i.e. its gravity) along with the object and purpose of the ECHR, namely to 'maintain and promote the ideals and values of a democratic society governed by the rule of law.'164 In Navalnyy, Selahattin Demirtaş (No 2), and Navalnyy (No 2), the three cases discussed above in which it has since applied this standard, it inferred the authorities' motivations from the circumstances, finding a violation of Article 18. In other words, the Court is no longer turning a blind eye to obvious abuses of power; the question then is whether this exhausts the scope of the provision.

A perhaps self-evident but necessary word of caution is in order here. Article 18 does not begin where the existence of a legitimate aim for a given

164 Merabishvili (n 10) para 307. 
limitation of rights ends. In other words, if for example the Court finds that a restriction of the right to freedom of assembly and association as per Article 11 ECHR was not applied 'in the interests of national security or public safety, for the prevention of disorder or crime, for the protection of health or morals or for the protection of the rights and freedoms of others', as provided by the provision, this does not automatically mean that Article 18 has been violated. Any other conclusion would not only negate the purpose of the explicit limitations clauses in Articles 8 to $11 \mathrm{ECHR}$, but it would also dilute the purpose of Article 18.

This was of concern to the Court in Merabishvili, and it is the rationale behind the predominant purpose test. ${ }^{165}$ In other words, to ensure that measures that the state has (in good faith) taken without a legitimate aim do not fall under Article 18, the Court requires that the abuse of power (in bad faith) be the predominant purpose for a given measures in order to find a violation of that provision. Focusing on the legitimate aim here is however a bit of a red herring: the real issue is whether there has been an abuse of power, i.e. whether the state has limited rights in bad faith, and not whether a given measure has a legitimate aim. Because proof of bad faith by the state had proven impossible for applicants to obtain in earlier cases, the Court rightly abolished that standard in Merabishvili. However, the predominant purpose test is an unsatisfactory solution to this problem. Bad faith and a legitimate aim can coexist, and the former is a big problem which - as will be shown in what follows matters beyond Article 18 .

\subsection{The Court's Loyalty Program}

In a recent article, Başak Çalı has discussed the 'bad faith' jurisprudence under Article 18 and the 'good faith' jurisprudence under other provisions. This latter case-law leads the Court to take a procedural approach to the review of measures taken by certain trusted states if these have received extensive consideration by domestic legislative processes and are not 'manifestly disproportionate.'166 In other words, the Court may be deploying a sort of loyalty program, taking a procedural approach to the review of applications against compliant states while applying a higher standard, namely one of substantive review, for non-compliant states.

\footnotetext{
165 Ibid para 303.

166 Examples mentioned in the article are SAS $v$ France (2014) 60 EHRR 11; Animal Defenders International $v$ the United Kingdom (2013) 57 E HRR 21; Von Hannover $v$ Germany (No 2) (2012) 55 EHRR 15 .
} 
Çalı argues that, together, these are two types of responses are coping strategies for the loss of overall support for the European human rights acquis in Member States. ${ }^{167}$ The 'bad faith' case-law under Article 18, she argues, responds to the realisation that states do not flout the Convention's requirements by error, or because of a lack of knowledge or awareness, but intentionally and from a position of disrespect for the ECHR and the Court. ${ }^{168}$ This should be seen against the background of states' 'attitude problem' towards the ECHR, and the development of 'anti-democratic governance structures' in a number of member states. ${ }^{169}$ In these conditions, trends towards limiting the rights of opposition groups go hand-in-hand with systemic challenges to the ECHR system's authority and its 'non-negotiable structural requirement of pluralist democracy and rule of law', while the growing number of repetitive cases that come before the Court 'reflects the domestic decay of rule of law' in these states. ${ }^{170}$

The vast spaces carved out for domestic decision-making in 'good faith' states, as described by Çall, is highly problematic. When it comes to the question of the legitimate aim of limitations of rights, this has led to acquiescence by the Court to vague interpretations of legitimate aims concerning, for example, the protection of 'religious feelings' ${ }^{171}$ or of 'living together.' ${ }^{172}$ In this regard, it should be pointed out that parliamentary debate does not provide a failsafe guarantee of a legitimate aim for a given limitation of rights. A parallel can be drawn to the reasoning used in Tyrer $v$ the United Kingdom, where the Court held that the fact that the corporal punishment known as 'birching' did not offend public opinion on the Isle of Man did not mean that it was not degrading, and that in fact it may have been favoured precisely because of its degrading nature. ${ }^{173}$ Generally speaking, it is problematic to assume that parliamentary discussions preclude the existence of an ulterior purpose. For example, regarding the non-violation finding made in the SAS $v$ France case, commentators alleged that a hidden agenda of the respondent state could not be excluded. ${ }^{174}$

\footnotetext{
167 Çalı (n 11).

168 Ibid 241.

169 Ibid 251.

170 Ibid 252.

171 ESv Austria App no 38450/12 (ECtHR, 25 October 2018) para 57.

172 SAS (n 166) paras 121-122.

173 Tyrer $v$ the United Kingdom (1978) 2 E HRR 1, para 31.

174 S Ouald Chaib and E Brems, 'Doing Minority Justice Through Procedural Fairness: Face Veil Bans in Europe' (2013) 2 Journal of Muslims in Europe, 1-26, 11-13 (as mentioned in Çalı (n 11$)$ 272).
} 
In contrast to this 'good faith' jurisprudence, concerning 'bad faith' states, Çalı argues, the Court's approach to the legitimate aim of a measure is characterised by higher levels of scrutiny and the possible application of Article 18. This, Çalı has argued, means that the Court risks being seen as 'an institution of double standards', and that its approach may be seen as politicised and unprincipled..$^{175}$

The issue of bad faith may seem to be ebbing out of the Court's Article 18 jurisprudence - since Merabishvili, applicants are no longer required to prove bad faith by the state. However, Article 18 is not just about states failing to pursue a legitimate aim when limiting rights, which would simply replicate the Convention's various limitations clauses. Instead, it is, and must continue to be, about feigned legitimacy and thus about bad faith.

Admittedly, applying Article 18 to only some states may not sit well domestically, and may lead to perceptions of states being singled out or misunderstood. On the other hand, some states have more serious issues with abuses of power and the rule of law than others. It should be recalled, of course, that not every rights restriction by a 'good faith' state will be found to be in compliance with the ECHR, and not every restriction by a 'bad faith' state will be found to violate Article 18. As Çalı herself notes, together, the two types of judgments are just a small fraction of the cases decided by the Court overall, and they occur in parallel with continued violation judgments against 'good faith' states and non-violation judgments (both regarding Article 18 and other provisions) against 'bad faith' states. Still, contrasting Çalı's two types of cases allows for the identification of what good and bad faith looks like to the Court.

The early Article 18 case-law required a level of proof of bad faith that was impossible for applicants to provide except in certain, fortuitous circumstances. ${ }^{176}$ For Çal, this is part of the Court's naïve adherence to the presumption of good faith. ${ }^{177}$ Today, after a number of states have challenged and continue to challenge the Court's authority, after numerous calls for increased subsidiarity and deference by the Court, after the Brighton Declaration and ensuing processes, however, the landscape is somewhat different. ${ }^{178}$

Writing on how human rights treaty bodies, courts, and other monitoring mechanisms can confront the threat that populism represents both for human rights and for these institutions themselves, Laurence Helfer has asked whether

\footnotetext{
175 Çalı (n 11) 270-271.

176 Gusinskiy (n 7$)$.

177 Çalı (n 11) 264.

178 See, on this, L Helfer, 'Populism and International Human Rights Institutions: A Survival Guide', iCourts Working Paper Series No 133 (June 2018) <https://papers.ssrn.com/sol3/ papers.cfm?abstract_id=3202633> accessed 9 December 2019.
} 
applying 'bespoke' legal doctrines like the one under Article 18 to populist governments is a good choice. This 'bespoke' system goes undefined, and could be taken to refer to the selection of states to which it is applied, or to the types of situations that it is meant to cover. Answering his own question in the negative, Helfer argues - much like Çalı - that this type of approach may 'add fuel to the fire of public opposition to external institutions that scrutinise and condemn populist leaders and their policies.' ${ }^{179}$

Helfer notes the ways in which populist regimes focus inwards, undermine opposing institutions, and dominate public discourse, and argues that 'a leitmotif of populist regimes is that the majority's fundamental rights and freedoms are under threat, thereby justifying restrictions on the rights of minorities. ${ }^{180}$ This raises an important implication. Arguably, Article 18 could be used for more than countering governments' efforts to silence opposition - it could also serve to counter this dominant threat narrative and flag, for example, abusive limitations of the rights of minorities or efforts to manipulate and distort social media. Applying Article 18 to these types of situations can help to signal the underlying intentions and draw attention to these processes; it could ultimately even approximate the aims of infringement proceedings, albeit without the same consequences. ${ }^{181}$ However, in this regard, we should recall that a limitation of a given Convention right or freedom without a permitted legitimate aim already represents a violation of that right or freedom, and that there must be some additional factors present in order to allow for a finding of a violation of Article 18. Nevertheless, instead of turning a blind eye, where respect for Convention values and the rule of law crumbles, the Court should take a stand, as it was intended to do under Article 18.

For Helfer, like Çalı, applying Article 18 against populist regimes will likely only strengthen opposition to international and regional institutions perceived as meddling with the policies of elected leaders. ${ }^{182}$ At the same time, excessive caution and a procedural approach carry their own risks, given that applying Article 18 in select circumstances could provide a sorely-needed opportunity to call out underlying tendencies and strengthen domestic prodemocracy movements. In short, and while are there are reasonable grounds for caution, we should not write off Article 18 purely because of the risk of backlash from populist regimes.

\footnotetext{
179 Ibid.

180 Ibid.

181 On infringement proceedings, see Article 46(4) ECHR, as used for the first time regarding Ilgar Mammadov (n 21) (Registrar of the Court's Press Release EC HR 390 (2017), 14 December 2017), which was incidentally an Article 18 case; Helfer (n 178).

182 Helfer $(\mathrm{n} 178) 14$.
} 
Nevertheless, time will tell whether Article 18 can actually make a difference in these contexts. Among other things, a case in which the Court found a violation of the provision has recently led to the first ever institution of infringement proceedings in accordance with Article 46(4) ECHR against Azerbaijan for potentially having failed to fulfil its obligation to abide by the Court's judgments. ${ }^{183}$ In that case, the Committee of Ministers noted that the respondent state failed to secure the release of the applicant, a regime-critical opposition politician who had been incarcerated in violation of Article 18. ${ }^{184}$ The respondent state refused to comply with the Court's judgment on this matter for three years, ${ }^{185}$ and only released Mr Mammadov - whom the Secretary General of the Council of Europe, Thorbjørn Jagland, has called a 'political prisoner' - in 2018, after five years of imprisonment and the instigation of the infringement proceedings. ${ }^{186}$ It is not entirely clear what the added value of the finding of an Article 18 violation in this regard was - except for making the Committee of Ministers' statements on the need for the applicant's release more emphatic and in any event measuring the 'effectiveness' of any given judgment of the Court is a fraught endeavour, but it is conversely also possible to argue, as above, that finding no violation of the provision in these cases or finding it unnecessary to examine the complaints made in this regard exerts a legitimising force.

Article $18 \mathrm{ECHR}$ is an idiosyncratic and neglected provision, but one which is of vital importance to the Convention. It was intended as a safeguard against bad faith restrictions of Convention rights, where a legitimate purpose claimed by the state masks an illegitimate, nefarious, bad faith one that undermines Convention values, for example the suppression of dissent or the neutralisation of political opponents. In the last few years, the Court has made headway in

\footnotetext{
183 Committee of Ministers, Interim Resolution CM/ResDH (2017) 429, Execution of the judgment of the European Court of Human Rights: Ilgar Mammadov against Azerbaijan, 5 December 2017.

184 Ilgar Mammadov (n 21) paras 142-143.

185 'Execution of Ilgar Mammadov' (n 183).

186 Council of Europe, 'Statement by Secretary General Thorbjørn Jagland on the release of human rights defender Ilgar Mammadov in Azerbaijan' (13 August 2018) <https://www .coe.int/en/web/portal/-/statement-by-council-of-europe-secretary-general-thorbj-rn -jagland-on-the-release-of-human-rights-defender-ilgar-mammadov-in-azerbaijan> accessed 9 December 2019.
} 
its interpretation of the provision, normalising its applicability and burden of proof so as to make its successful invocation by applicants a realistic possibility.

At the same time, questions remain: since the 2017 Merabishvili Grand Chamber judgment and the resulting move away from bad faith in testing whether there has been a violation of Article 18, the distinction of Article 18 from Article 17 raises issues, as does the question of how to counter limitations of rights that are predominantly legitimate but have an 'unhealthy core'. This article has argued for a clear distinction between abusive reliance on rights by their bearers, as enshrined in Article 17 ECHR, and bad faith limitations of individuals' rights by the state. It has also highlighted some of the problems with the 'predominant purpose test' established in Merabishvili. The Court's own unease with this test is evident: it has repeatedly limited its analysis under Article 18 so as to avoid having to examine measures with both legitimate and illegitimate aims. The referral of the Selahattin Demirtas (No 2) case to the Grand Chamber may soon provide a fresh opportunity for the Court to confront some of these issues head-on.

Today, given ongoing discussions about national sovereignty and the Court's subsidiarity, backlash against the Court, and growing support for tendencies that may undermine Convention values in a number of member states, Article 18 has added value and a distinctively important role to play. The presumption of good faith makes the Convention system workable, but it cannot mean that the Court is blind to bad faith where it does arise. While the role of Article 18 cannot be too broad, given the serious implications of a violation and the political nature of many of the questions involved, Article 18 is a vital safeguard of democratic values and the rule of law, and it should not be deprived of its purpose. 